\title{
Pharmacognostic Evaluation of Epilobium hirsutum Linn.
}

\author{
N. A. Sheikh ${ }^{1,2^{*}}$, T. R. Desai ${ }^{2}$, R. D. Patel ${ }^{3}$ \\ 'Department of Pharmacology, Smt. C. V. Gajera Pharmacy Mahila College, Chakkargadh Road, Amreli 365601 (Gujarat), INDIA. \\ 2Department of Pharmacology, School of Pharmacy, R K University, Bhavnagar Highway, Kasturbadham, Rajkot 360020 (Gujarat), INDIA. \\ ${ }^{3}$ Department of Pharmacognosy, Smt. C. V. Gajera Pharmacy Mahila College, Chakkargadh Road, Amreli 365601 (Gujarat), INDIA.
}

\begin{abstract}
Background: Epilobium hirsutum Linn. (Onagraceae) is used widely as traditional medicine for its various medicinal values. Despite the popular utilization of this plant, still no conclusive study has been reported so far regarding the pharmacognostical standardization. Aim: Thus, the present study was aimed to scientifically establish a standard monograph of E. hirsutum on the basis of pharmacognostical aspects. Material and methods: Macroscopic, qualitative and quantitative microscopic characters of $E$. hirsutum were analyzed. Results: The diagnostic characters of the E. hirsutum were evaluated based on the macroscopical and microscopical characters. Conclusion: The obtained qualitative and quantitative standards will provide referential information for correct identification, purity, stan-
\end{abstract}

dardization and preparation of monograph of E. hirsutum.
Key words: Epilobium hirsutum Linn, Onagraceae, Great willowherb, Hairy willowherb, Great hairy willowherb.

\section{Correspondence:}

N. A. Sheikh,

Assistant Professor, Department of Pharmacology,

Smt. C. V. Gajera Pharmacy Mahila College, Chakkargadh Road,

Amreli 365601 (Gujarat), INDIA.

Ph no: +919974756353

Fax no.: +912792232327

Email: wsheikh2@gmail.com

DOI : 10.5530/pj.2016.3.8

\section{INTRODUCTION}

Epilobium hirsutum Linn. is a flowering plant belonging to family Onagraceae, commonly known as great willowherb and great hairy willowherb or hairy willowherb. ${ }^{1}$ E. hirsutum is a large, annual, densely covered with white hair. The leaves are 1-3 in number, $2-12 \mathrm{~cm}$ long, 0.5-3.5 cm wide, lanceolate, stem-leaves usually opposite, sessile, stem clasping and small teeth shaped. The flowers are 10-16 mm long, pink purple, axillary in long and short leafy racemes at the end of stem and branches, calyx-tube liner, 4 angled, lobes 4 short pointed, soon falling off. Petals 4, erect or spreading, notched, stamens 8, alternate ones longer, stigmas 4 , distinct, erect at first, recovered afterwards. The capsule is $4-9 \mathrm{~cm}$ long. There are many seeds which are, small, tipped, with a tuft of long white hairs. ${ }^{2}$

The native range of E. hirsutum includes Mediterranean region, Europe, Asia, Africa and India particularly in Jammu and Kashmir, it is distributed in the western Himalaya up to an altitude of 7,000 $\mathrm{ft}^{3-4}$ Common habitats include marshland, ditches and the banks of rivers and streams. Earlier claim shows that the E. hirsutum has antinociceptive, ${ }^{5}$ anti-inflammatory, ${ }^{6}$ antioxidant, ${ }^{7}$ it alters the protein synthesis by alteration in enzyme and mRNA, ${ }^{8}$ in-vitro iron chelation activity. ${ }^{9}$ The plant is also used as an antimicrobial, antitumor and in the treatment of enlarged prostate, prostatitis, cystitis, burning feeling when urinating, and burning feeling after prostate operation. ${ }^{10}$ Despite the popular utilization of this plant, still no conclusive study has been reported so far regarding the pharmacognostical standardization. Hence, the present cram was focused to investigate the pharmacognostical properties of E. hirsutum.

\section{MATERIAL AND METHODS}

\section{Plant collection and authentication}

E. hirsutum was collected in the flowering stage from the fields of Chatterhama, Hazartbal, Srinagar, Jammu and Kashmir, India during August 2013. It was authenticated by Mr. Akhtar H. Malik, Curator, Centre for biodiversity and taxonomy, Department of Botany, University of Kashmir, Jammu and Kashmir, India (1914-KASH).

\section{Chemicals and instruments}

All reagents and chemicals used for pharmacognostic screening were analytical grade. Compound microscope was used for the study. The photography was done by using microscope camera using Toupview software. Camera lucida was used for determination of quantitative microscopical characters.

\section{Morphology and Microscopy}

The morphological studies were carried out by using simple determination technique like shape, size, colour, odour, taste, surface and fractures. Microscopic studies were carried out by preparing thin hand section of leaf, stem and root. The sections were cleared with alcohol and stained. Histochemical reactions were applied with concentrated hydrochloric acid and phloroglucinol for identification of lignified elements, iodine solution for starch grains, Sudan red-III for cuticle layer and oil globules, Ruthenium red for mucilage and acetic acid for calcium oxalate crystals. The leaf constants like stomatal number, stomatal index, vein termination number, vein islet number and palisade ratio were measured using camera lucida. ${ }^{11}$

\section{Powder microscopy}

The powder microscopy of shade dried E. hirsutum was carried out by using various reagents for the identification of powder characteristics. ${ }^{12-13}$

\section{RESULTS}

\section{Morphological characteristics}

The morphological studies revealed (Figure 1) that the leaves was simple, sessile, green in colour, oblong-lanceolate in shape, 2-12 cm long, 0.5-3.5 $\mathrm{cm}$ wide, aromatic odour with characteristic and aromatic taste. Leaves had sharply serrulate margin, acute apex, symmetrical base, reticulate pinnate venation, thin texture and pubescent surface. The stem was green in colour, cylindrical in shape, about $0.5-1 \mathrm{~m}$ long, aromatic odour 


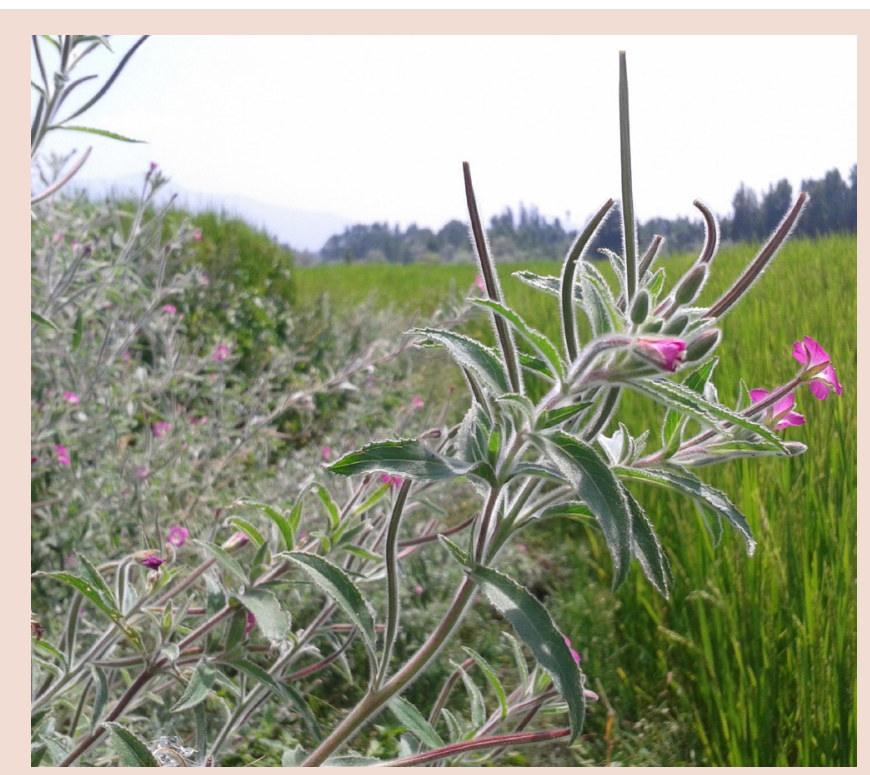

Figure 1: Plant of E. hirsutum.

with characteristic and aromatic taste. The surface was pubescent with short fracture. The root was brownish in colour, cylindrical in shape, about $8 \mathrm{~cm}$ long and $0.5-1 \mathrm{~cm}$ in diameters, the root was odourless and tasteless. Longitudinal ridges and rootlets with short fracture were present on surface of root. The flowers were large and have 4 notched petals. The size of flower was $10-16 \mathrm{~mm}$ long and purple pink in color. The sepals were green; stigma was white with 4 lobes. The fruits were capsular and slender 5-8 cm long, brownish in color and containing numerous seeds embedded in fine silky fluff. The seeds were oblong and flattened in shape, $1 \mathrm{~mm}$ long and had nearly white hairs.

\section{Qualitative microscopical characteristics}

Transverse section of leaf

The transverse section of leaf was shows that upper and lower epidermis of lamina consists of single layered, rectangular cells, distinct cuticle, it also contain uniseriate, unicellular covering trichomes (Figure $2 \mathrm{~A}-\mathrm{B}$ ), whereas Figure $2 \mathrm{C}$ shows anomocytic type of stomata, lower epidermis contents more stomata. Mesophyll consist palisade single layered, compact cells, with several layered spongy parenchyma, oil globules and vacuoles were present throughout mesophyll. Midrib was consists of upper and lower epidermis same as that of lamina, collenchyma present below upper epidermis and above lower epidermis, vascular bundles were arc shaped hydrocentric and were present more towards dorsal side, rest of midrib was filled with normal parenchymatous cells (Figure 2 D). It also contains brownish matter, needle shaped calcium oxalate crystals and starch grains (Figure $2 \mathrm{E}-\mathrm{F}$ ).

\section{Transverse section of stem}

Transverse section of stem shows that epidermis consists of single layered, quadrangular cells and thick cuticle. It also contains uniseriate, unicellular covering trichomes. Hypodermis was present below epidermis consist of few layer of collenchyma and clorenchyma cells. Cortex consists of several layers of thin walled cellulosic parenchyma cells. Mature stem contains of brownish matter in cortex. Unlignified group of fibers were present outside the phloem. Vascular bundle was closed collateral type; phloem contains of sievetubes and companion cells. Xylems were well developed, consists of xylem parenchyma and vessels. Pith was large, thin walled, polygonal parenchyma cells (Figure 3 A-B). Cortex

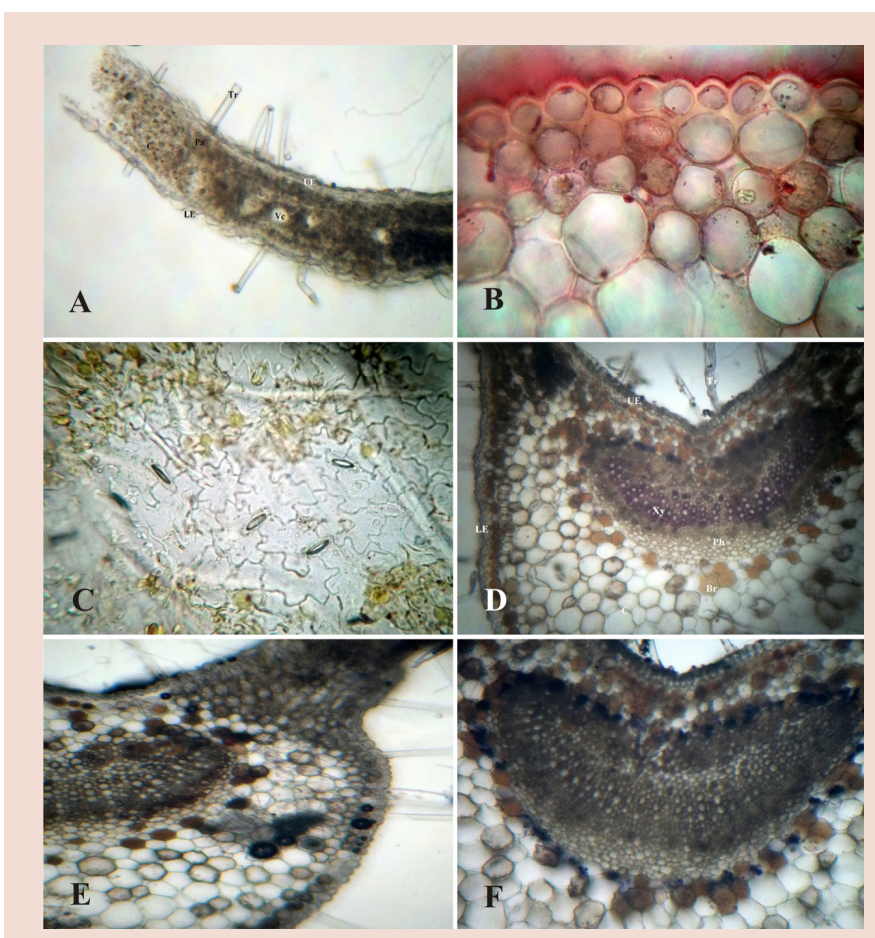

Figure 2: Photomicroscope of transverse section of leaf of E. hirsutum (A) Lamina (10X); (B) Cuticle layer; (C) Surface preparation shows anomocytic stomata; (D) Midrib; (E) Needle shaped calcium oxalate crystals; (F) Starch grains. (UE: upper epidermis, LE: lower epidermis, Tr: Trichome, Vc: Vacuole, Pa: Pali-
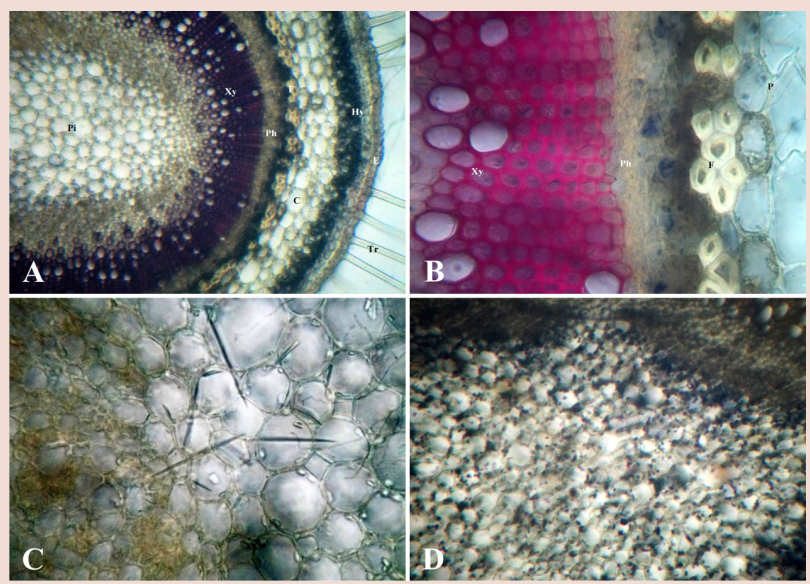

Figure 3: Photomicroscopy of transverse section of root of E. hirsutum (A) Root (10X); (B) Needle shaped calcium oxalate crystal. (Co: Cork, Br: Brownish matter, C: Cortex, Ph: Phloem, Xy: Xylem, Pi: Pith).

and pith also contains needle shaped calcium oxalate crystals and starch grains (Figure $3 \mathrm{C}-\mathrm{D}$ ).

\section{Transverse section of root}

The transverse section of root revealed that cork consists of several layers of thin walled, polygonal cells with brown content. Cortex consists of several layers of thin walled, polygonal parenchymatous cells, brownish matter and needle shaped calcium oxalate crystals. The phloem shows phloem parenchyma, sievetubes and unlignified phloem fibers. Xylem 


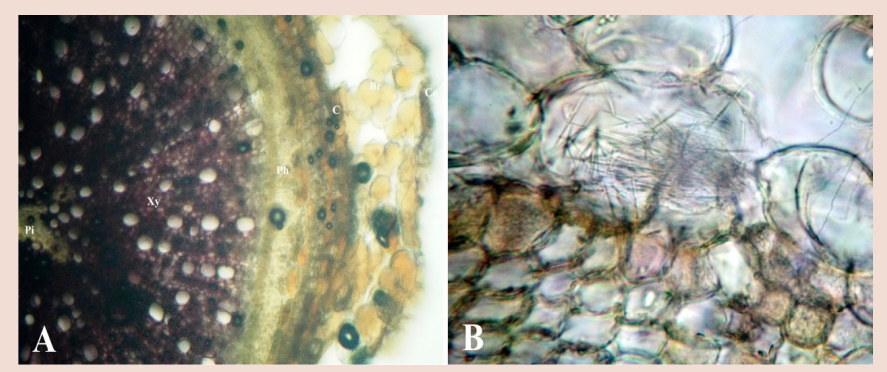

Figure 4: Photomicroscopy of transverse section of root of E. hirsutum (A) Root (10X); (B) Needle shaped calcium oxalate crystal. (Co: Cork, Br: Brownish matter, C: Cortex, Ph: Phloem, Xy: Xylem, Pi: Pith).

Table 1: Quantitative microscopy of leaf of E. hirsutum

\begin{tabular}{cc}
\hline Leaf constant & Mean value \\
\hline Stomatal number & \\
Upper surface & $46.25 \pm 2.50$ \\
Lower surface & $57.50 \pm 2.89$ \\
Stomatal index & \\
Upper surface & $14.54 \pm 1.56$ \\
Lower surface & $18.04 \pm 2.15$ \\
Vein islet number & $72.50 \pm 2.89$ \\
Vein termination number & $28.75 \pm 2.50$ \\
Palisade ratio & $7.25 \pm 0.50$ \\
\hline
\end{tabular}

consists of xylem parenchyma, vessels and medullary rays. Pith was very small and consists of parenchyma cells (Figure 4 A-B).

\section{Powder characteristics}

The shade dried powder of E. hirsutum shows greenish brown colour having characteristic odour and sweet, bitter, sharp and sour taste. Epidermis consists of thin walled, irregular parenchymatous cells with wavy outline. Trichomes were uniseriate, unicellular. Parenchyma shows thin walled polyhedral cells with intercellular space. Cork shows polygonal isodiametric cells with brownish matter. Mesophyll consists of spongyparenchyma with vascular strands. Xylem vessels were lignified spiral shaped. Fibres were lignified, thick walled and cylindrical in shape. Starch was simple, oval and rounded shaped. It also contains brownish matter whereas the stomata were of anomocytic type (Figure $5 \mathrm{~A}-\mathrm{J}$ ).

\section{Quantitative microscopical characteristics}

These values were especially useful for identifying the different species of genus and also helpful in determination and authenticity of the plant. The results were shown in Table 1.

\section{DISCUSSION}

The pharmacognostic evaluation is the first step towards the confirmation of identity and to assess the purity and quality of plant. Before the use of plant it is necessary that standards should be available to control and check the identity of the plant along with its quality. As per WHO the macroscopic and microscopic description of medicinal plant is the initial step towards establishing its identity, it should be carried out before any tests are undertaken. ${ }^{14}$

\section{CONCLUSION}

The present work deals with the pharmacognostic study of E. hirsutum. The morphological and microscopical study of plant and powder were

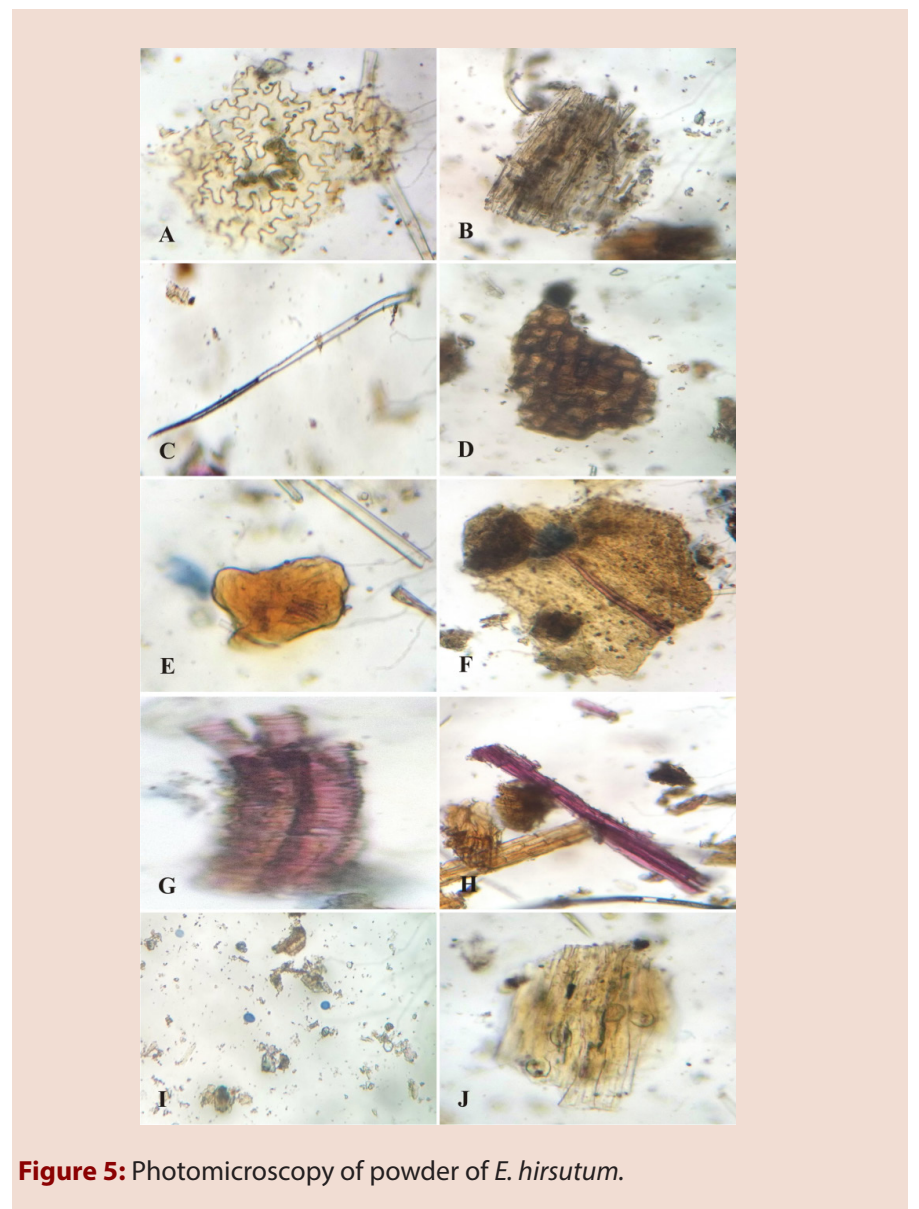

studied for their specific characters. The present study will provide useful information for correct identification of plant. In addition the results of the present study could be useful for preparation of a monograph of the E. hirsutum.

\section{ACKNOWLEDGEMENT}

The authors are grateful to Principal of Smt. C. V. Gajera Pharmacy Mahila College, Amreli (Gujarat), India for providing the facility to conduct the experimental work.

\section{CONFLICT OF INTEREST}

The authors have no conflict of interest to declare.

\section{ABBREVIATION USED}

mm: millimeter; cm: centimeter; m: meter; ft: feet; E: Epidermis; UE: upper epidermis; LE: lower epidermis; Hy: Hypodermis; Tr: Trichome; C: Cortex; F: fibers; Xy: Xylem; Ph: Phloem; Pi: Pith; Vc: Vacuole; Pa: Palisade; Br: Brownish matter.

\section{REFERENCES}

1. Kraksek SS, Kreft S, Kladnik A, Draslar K, Jogan N, Dermastia M. Morphology and glandular activity of unicellular trichomes of Epilobium hirsutum. Biol Plantarum. 2011;55(1):149-52.

2. Bamber CJ. Plants of the Punjab: A descriptive key to the flora of the Punjab, North-West Frontier Province and Kashmir. Lahore: Superintendent Government printing Punjab 1916; 324

3. Hajimoradloo A, Pakravan S, Ghorbani R. Effect of dietary willow herb, Epilobium hirsutum extract on growth performance, body composition, haematological parameters and Aeromonas hydrophila challenge on common carp, Cyprinus carpio. Aquac Res. 2012;43(6):861-9. 
4. Anonymous. The Wealth of India. A dictionary of Indian raw material and industrial products. New Delhi: Publication and Information Directorate (CSIR). vol3:2003; 180

5. Pourmorad F, Ebrahimzadeh MA, Mahmoudi M, Yasini S. Antinociceptive activity of methanolic extract of Epilobium hirsutum. Pak J Biol Sci. 2007; 10(16):2764-7.

6. Kiss AK, Kiarszys U, Piwowarski J, Staszewska A, Bazylko A. Contribution of oenothein B in the anti-inflammatory activity of Epilobium sp. Extracts. Planta Med. 2008;74(9):PA93

7. Wojdyło A, Oszmianski J, Czemerys R. Antioxidant activity and phenolic compounds in 32 selected herbs. Food Chem. 2007; 105(3): 940-949.

8. Karakurt S, Semiz A, Celik G, Gencler-Ozkan AM, Sen A, Adali O. Epilobium hirsutum alters xenobiotic metabolizing CYP1A1, CYP2E1, NQO1 and GPx activities, mRNA and protein levels in rats. Pharm Biol. 2013;51(5):650-8.
9. Ebrahimzadeh MA, Pourmorad F, Bekhradnia AR. Iron chelating activity, phenol and flavonoid content of some medicinal plants from Iran. Afr J Biotechno. 2008;7(18):3188-92

10. Ivancheva S, Nikolova M, Tsvetkova R. Pharmacological activities and biologically active compounds of Bulgarian medicinal plants. Phytochemistry: Adv Res. 2006;87-103.

11. Khandelwal KR. Practical Pharmacognosy: Techniques and Experiments. $19^{\text {th }}$ ed. Pune: Nirali Prakashan;2008:49-70.

12. Iyengar MA. Pharmacognosy of powdered crude drugs. $2^{\text {nd }}$ ed. Manipal. 1980.

13. Jackson BP, Snowdon DW. Atlas of microscopy of medicinal plants, culinary herbs and spices. $1^{\text {st }}$ ed. New Delhi: CBS Publishers and Distributors (P) Ltd, 1992.

14. World Health Organisation. Quality control methods for medicinal plants. WHO library. Geneva, Switzerland. 2002:28-31.

\section{PICTORIAL ABSTRACT}

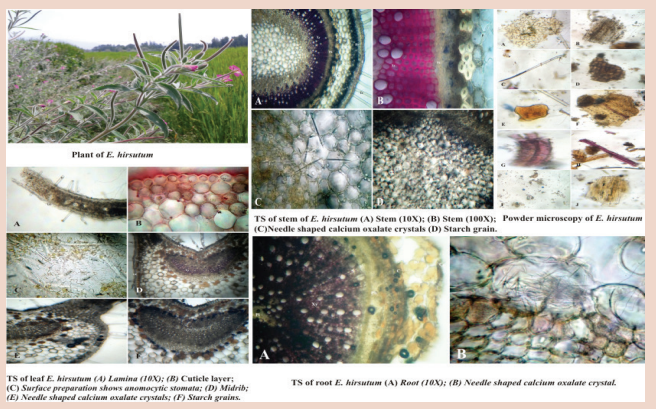

\section{SUMMARY}

- The morphological characters of E. hirsutum were established.

- The transverse section of leaf shows lamina with single layered epidermis, trichomes, anomocytic stomata, vacuole, palisade, cortex, mesophyll, midrib with single layered epidermis, vascular bundles, brownish matter, needle shaped calcium oxalate crystals and starch grains.

- Stem contains single layered epidermis, hypodermis, cortex with several layers, pith, trichomes, fibers, phloem, xylem, needle shaped calcium oxalate crystals and starch grains.

- Root shows the presence of cork, cortex, pith, phloem, xylem, brownish matter and needle shaped calcium oxalate crystals.

- The powder characteristics of E. hirsutum revels the presence of Epidermis, Parenchyma, trichomes, cork, brownish matter, mesophyll, xylem, Starch grain, fibers, stomata.

- Various quantitative microscopy parameters of E. hirsutum were also established.

\section{ABOUT AUTHORS}

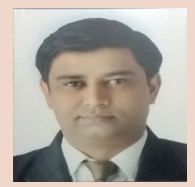

Mr. N. A. Sheikh: Working as Assistant Professor at Department of Pharmacology, Smt. C.V. Gajera Pharmacy Mahila College, Amreli and as PhD scholar at RK University, Rajkot. He is having 8 years of teaching experience in the field of Pharmacology. Mr. N. A. Sheikh has published 18 research papers in national and international peer reviewed journals. His area of research is Pharmacology, toxicology, Pharmacognosy and Phytochemistry.

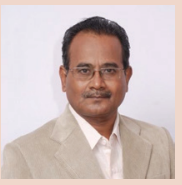

Dr.T. R. Desai: Obtained his PhD degree in pharmacology in 2005 from Saurashtra University, Rajkot. Currently he is positioned as Director, School of Pharmacy, RK University. Dr. Desai has 33 years of teaching experience. He has convened several conferences. He has 15 review and more than 60 research papers on his name. Dr. Desai had guided many postgraduate and PhD students. Four students were awarded PhD under his guidance and four were enrolled as PhD scholar. His area of research is clinical pharmacology and Toxicology.

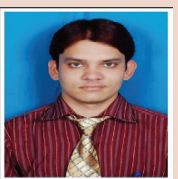

Mr. R. D. Patel: Working as Assistant Professor at Department of Pharmacognosy, Smt. C.V. Gajera Pharmacy Mahila College, Amreli. Mr. Patel is having 8 years of teaching experience in the field of Pharmacognosy. He is a $\mathrm{PhD}$ research scholar at NIMS University, Jaipur. He has published more than 30 research papers. Mr. Patel is a life time member of APTI and IPGA. His area of research is Pharmacognosy, Phytochemistry and Pharmacology. 